Marta BALCEREK

Uniwersytet im. Adama Mickiewicza, Poznań

\title{
Samorząd gospodarczy w koncepcji społecznej gospodarki rynkowej w RFN w latach 1949-1963
}

1.

Drzełomowe zdarzenia zawsze przynoszą spory ideologiczne. W obliczu kryzysu zastane systemy: polityczny, społeczny i gospodarczy tracą moc oddziaływania. Państwo uzyskuje czystą kartę, która będzie następnie zapisana zgodnie ze specyfiką zmieniających się czasów ${ }^{1}$. Zazwyczaj potrzeba rewizji doktryny politycznej podporządkowuje zmianę doktryny ekonomicznej. W Niemczech Zachodnich po drugiej wojnie światowej było odwrotnie - zmiana doktryny ekonomicznej wymusiła zmianę doktryny politycznej.

Obywatele Niemiec po okresie przemian wojennych pragnęli doprowadzić do życia w państwie prawa, gdzie podstawy ich funkcjonowania znalazłyby oparcie w przepisach prawnych oraz byłyby szanowne przez organy władzy publicznej. Przed państwem zostało postawione ważkie zadanie ustanowienia takich ram prawnych, które gwarantowałyby pożądany kierunek zmian systemu politycznego, społecznego oraz gospodarczego. Jeżeli otoczeniem systemu politycznego jest system społeczny, następnie relacje, jakie zachodzą w społeczeństwie wpływają na system ekonomiczny przeto system polityczny jest uwarunkowany tymi dwoma układami².

1 Por. U. Zgóra-Jonszta, Ordoliberalizm a społeczna gospodarka rynkowa Niemiec. Możliwości jej realizacji w Polsce, Katowice 1999, s. 17.

2 O końca lat 40. XX wieku obserwuje się kontekstualizm polityki. Wskutek tego nie da się oddzielić systemu politycznego od systemu społecznego. Dlatego też przyczynowe powiązania przebiegają między społeczeństwem a systemem politycznym w kierunku od społeczeństwa do systemu; por. J. G. March, J. P. Olsen, Instytucje. Organizacyjne podstawy polityki, Warszawa 2005, s. 12. 
Przemiany społeczno-polityczne, jakie wywarły znaczący wpływ na kształtowanie się nowej doktryny ekonomicznej w powojennych Niemczech nie sposób w tym artykule szczegółowo omówić, ale krótki szkic jest niezbędny jako tło do dalszej analizy. Jak wiadomo w wyniku przegranej wojny i bezwarunkowej - 8 maja 1945 roku - kapitulacji Niemiec hitlerowskich, obszar III rzeszy znalazł się pod okupacją mocarstw zwycięskiej koalicji antyhitlerowskiej: Stanów Zjednoczonych, Wielkiej Brytanii i Związku Radzieckiego. Odpowiednio powstały strefy okupacyjne: amerykańska, angielska, radziecka; powstała również strefa francuska. Terytorium owych stref zarządzone było przez władze wojskowe wymienionych mocarstw. Równocześnie pod nadzorem okupacyjnych władz wojskowych rozpoczął się proces demilitaryzacji, denazyfikacji, dekartelizacji i demokratyzacji obszaru byłej Rzeszy Niemieckiej, a wraz z tym postępował proces tworzenia podstaw politycznych i ekonomicznych nowego niemieckiego państwa prawa. Rychło jednak ujawniły się głębokie różnice wśród sojuszników co do ustroju politycznego i gospodarczego przyszłego państwa niemieckiego. Różnice te były tak głębokie, że ostatecznie na obszarze byłej III Rzeszy Niemieckiej powstały w 1949 r. dwa odrębne państwa, mianowicie: Republika Federalna Niemiec, obejmująca strefy okupacyjne Stanów Zjednoczonych, Wielkiej Brytanii i Francji oraz na obszarze strefy radzieckiej-Niemiecka Republika Demokratyczna ${ }^{3}$.

Nowopowstałe państwa niemieckie różniły się diametralnie pod względem ustroju politycznego i gospodarczego. Republika Federalna Niemiec, w porównaniu do autorytarnej Niemieckiej Republiki Demokratycznej, w sferze gospodarczej postulowała powrót do leseferyzmu, z wiarą w siłe sprawczą jednostki do podejmowania wyzwań stawianych przez wolny rynek. Ta druga natomiast zakładała, zgodnie z doktryną realnego socjalizmu, kolektywizm oraz wykonywaniem przez państwo funkcji opiekuńczej wobec jednostek. Powojenne Niemcy nie były gotowe do przyjęcia ani neoliberalnej koncepcji gospodarki wolnorynkowej ani gospodarki centralnie planowanej. Przestrzeń powstała na styku tych dwóch rozwiązań zrodziła potrzebę przyjęcia koncepcji, która odpowiadałoby warunkom, w jakich znalazły się Niemcy po drugiej wojnie światowej.

Wspomniana „trzecia droga” polegała na znalezieniu „złotego środka” pomiędzy kolektywizmem a liberalizmem. Stąd też, aby przeciwdziałać

3 Por. S. Cyganek, Izby przemysłowo-handlowe w Polsce $i$ w Niemczech, Poznań 2004, s. 50-59. 
narastającej fali kryzysu, w społeczeństwie niemieckim, należało przeprowadzić głębokie reformy. Rynek, mimo iż był niedoskonały i wymagał korekt ze strony państwa, nie dał się jednak zastapić. Dlatego pojawiła się koncepcja odrodzenia rynku w duchu doktryny zwanej ordoliberalizem ${ }^{4}$. Ten nurt ekonomii był właśnie ,złotym środkiem” pomiędzy socjalistycznym kolektywizmem a klasycznym liberalizmem. W nowopowstałej Republice Federalnej Niemiec był filozofią społeczną głównej partii politycznej Unii Chrześcijańsko-Demokratycznej. Nawiązywał do rodzimej filozofii społecznej XVIII i XIX wiecznej (Fichte, Hegel, Schelling i inni) i opartej na tej filozofii niemieckiej doktrynie ekonomicznej tzw. historyz$\mathrm{mu}^{5}$. Na porządek w sensie ordo składają się trzy zgodne ze sobą płaszczyzny: struktura społeczeństwa wraz z odpowiadającym jej systemem wartości, władza państwowa i prawo. Ordoliberalizm głosił stabilny i zrównoważony ład społeczny oparty na harmonii interesów wszystkich grup społecznych. Stał na gruncie gospodarki rynkowej opartej na wolności i konkurencji, z odpowiedzialnością socjalną; dopuszczał interwencjonizm państwa w sferze ustawodawstwa socjalnego i polityki społecznej ${ }^{6}$.

\section{2.}

Zmęczone i upokorzone społeczeństwo niemieckie potrzebowało wiary w ideę silnego państwa „które integrowałoby całą wspólnotę w imię wyższych wartości, nie dopuszczając do preponderancji, czyli przewagi indywidualnych interesów jednostek ${ }^{7}$. Idea aktywnej roli państwa w gospodarce była silnie zakorzeniona w społeczeństwie niemieckim. Jednym z pierwszych przedstawicieli ordoliberalizmu był Wilhelm Röpke, który już w 1923 roku w dziele „Wirtschaftlicher Liberaslismus und Staatsge-

4 Do przedstawicieli ordoliberalizmu zalicza się: Alexandra Rüstowa (1885-1963), Wilhelma Röpke (1899-1966), Waltera Euckena (1891-1950), Ludwiga Erharda (1897-1977), Franza Böhma (1895-1977) i Alfreda Müllera-Armacka (1901-1978).

5 Por. S. Wykrętowicz, Samorzad jako wyraz demokracji obywatelskiej, w: Samorzad w Polsce. Istota, formy, zadania, Poznań 2008, s. 41; E. Taylor, Historia rozwoju ekonomiki, t. I, Poznań 1967, s. 204 i n.

6 R. Skarzyński, Państwo i społeczna gospodarka rynkowa. Główne idee polityczne ordoliberalizmu, Warszawa 1994, s. 37.

7 Por. T. Grabkowski, Rola państwa w gospodarce RFN. Aspekty ogólne i militarno-ekonomiczne, Warszawa 1976, s. 11. 
danke" ${ }^{\text {" }}$ wskazał potrzebę zmiany roli państwa w stosunkach gospodarczych, a mianowicie państwo miało wykonywać funkcję arbitra w społeczeństwie w celu łagodzenia sprzecznych interesów pomiędzy małymi grupami społecznymi oraz zwalczania monopoli kreowanych przez gospodarkę wolnorynkową ${ }^{9}$. Ordoliberalizm jako doktryna liberalno-chrześcijańska odpowiadał ówczesnemu ugrupowaniu znajdującemu się od 1949 r. u steru władzy, czyli Unii Chrześcijańsko-Demokratycznej. Wymiar metafizyczny, w szczególności przez związek z religijnością oparty na idei ordo, zyskiwał na atrakcyjności w odbiorze społecznym. Ład rynkowy odzyskał moralny sens, ponieważ norma została odczytana z prawa natury. W ten sposób normy i wartości nie były jedynie dziełem człowieka, ale elementem wyższego porządku rzeczy. Ordo stało się pewnego rodzaju drogowskazem, w którym kierunku miało podążać odradzające się po wojnie państwo niemieckie. W. Eucken, uważany za ojca duchownego ordoliberalizmu ${ }^{10}$, traktował ordo jako z góry ustanowioną harmonię, której prawom człowiek się podporządkowat ${ }^{11}$. Stanowiło to podstawę do tworzenia nowego porządku w aspekcie społecznym, politycznymi i prawnym. Ordo to przede wszystkim tworzenie ram prawnych, w granicach, których nastąpi rozwój organów, organizacji i instytucji, które zapewnią prawidłowe reprezentowanie interesów całego społeczeństwa. Idea ta stanowi zatem zalążek idei państwa prawa w ładzie powojennym, w jakim znalazły się powojenne Niemcy.

Müller-Armack podkreślał, że ordo ma znaczenie porządku duchowego, wytworzonego poprzez prawa rządzące konkurencją. W rzeczywistości chodziło o to, aby ład zbudowany był w drodze naturalnej, a nie w wyniku rewolucji przez zwolenników kolektywizmu. Jest to ład będący efektem historii, czyli tego co obiektywne; natomiast wszelkie działania człowie$\mathrm{ka}$, w celu wytworzenia odmiennego porządku są nieobiektywne ${ }^{12}$.

Przeprowadzanie reformy gospodarczej w powojennych Niemczech zostało oparte na poglądzie Euckena o systemie ekonomicznym, którego

8 W. Röpke, Wirtschaftlicher Liberalismus und Staatsgedanke, w: Gegen die Brandung, Erlenbach 1959, s. 45 i n.

9 J. Lewandowski, Neoliberałowie wobec współczesności, Gdynia 1991, s. 100; K. Chojnicka, W. Kozub-Ciembrowicz, Doktryny polityczne XIX i XX wieku, Kraków 2000, s. 126.

${ }^{10}$ R. Tokarczyk, Współczesne doktryny polityczne, Zakamycze 1998, s. 74.

11 J. Lewandowski, Neoliberałowie wobec..., op. cit., s. 99.

12 A. Müller-Armack, Wirtschaftspolitik in der sozialen Marktwirtschaft, w: P. Boarman, Der Christ und soziale Martktwirtschaft, Stutttgart 1955, s. 88. 
podstawą powinna być wolna konkurencja - najbardziej idealna forma w modelu gospodarki rynkowej ${ }^{13}$. Uważał on, mianowicie, że wolna konkurencja nie może działać swobodnie w ładzie społeczno-gospodarczym. $\mathrm{Na}$ organizmie państwowym spoczywa zatem odpowiedzialność za zahamowanie przenikania skutków synkretyzmu kulturowego oraz ideologicznego. Stąd też musi ono rozpoznawać jasno swoje zadania, czyli bronić kapitalizmu przeciwko kapitalistom; co oznacza tworzenie ram prowadzenia działalności gospodarczej oraz wskazywania granic konkurencji ${ }^{14}$.

Mimo, iż ordoliberałowie uważali system rynkowy za najbardziej doskonały, wiedzieli jednak, że jest on labilny oraz bardzo kruchy. Zdaniem Euckena: „konkurencja doprowadza do tego, że wolność i ład są wtedy w równowadze, kiedy wolność i odpowiedzialność ściśle łączą się ze sobą uzyskując optymalny zakres"15. Owa zasada optymalizacji wyrażała się w ponoszeniu przez jednostkę odpowiedzialności nie tylko za swój los, ale przede wszystkim za interesy społeczeństwa. Jednostka zatem wykonuje powinności oraz obowiązki, jakie zostały na nią nałożone w związku z członkostwem w szerszej grupie społecznej. Wolność w tym ujęciu była rozumiana w sensie pozytywnym i negatywnym. Poprzez stworzenie instytucjonalnej infrastruktury dla gospodarki rynkowej zachowano możliwości działania chronione w obszarze przedsiębiorczości. Wolność w sensie negatywnym oznaczała brak ingerencji z zewnątrz. Obszar rynku został ściśle określony prawem, w ramach którego przedsiębiorca mógł swobodnie funkcjonować znając uprzednio konsekwencje, jakie jego działalność mogłaby wywołać. Tymczasem wolność w sensie pozytywnym rozumiano jako udzielenie pomocy osobom, którym nie powiodło się na rynku. Poprzez otrzymaną pomoc, jednostka mogłaby ponownie spróbować

13 W. Eucken odwoływał się do Maxa Webera poszukując rozwiązań liberalnych łączących fakty historyczne i dane statystyczne z nurtami teoretycznymi. Stąd też najprawdopodobniej można było wprowadzić na grunt gospodarki niemieckiej koncepcje wywodzące się z praktyki i doświadczeń empirycznych. Eucken sklasyfikował systemy gospodarcze jako typy idealne. Idealny typ np. gospodarki centralnie sterowanej przeciwstawił aprobowanej czystej gospodarce rynkowej. W ramach czystej gospodarki rynkowej analizował 5 idealnych form rynkowych - monopol, częściowy monopol, oligopol, częściowy oligopol i konkurencję jednostek z uwagi na zakresy potrzebnej wolności ekonomicznej jednostek zajmujących się przedsiębiorczością; por. J. Lewandowski, Neoliberałowie wobec..., op. cit., s. 99.

14 Por. W. Eucken, Grundsätze der Wirtschaftspolitik, Tübingen 2004; W. Eucken, Freiheit und wettbewerbliche Ordnung, München 2000.

15 W. Eucken, Podstawy polityki gospodarczej, Poznań 2005, s. 69 i n. 
swoich sił podejmując aktywne uczestnictwo w grze rynkowej np. jako przedsiębiorca lub też pasywne uczestnictwo polegające na dystrybucji określonego minimum egzystencjalnego.

Ordoliberałowie uważali, że rynek jest systemem demokratycznym, w którym konsumenci wypowiadają się każdego dnia na temat tego, co powinno być produkowane ${ }^{16}$. Stąd też konkurencję uważano za kluczowy mechanizm rynkowy, ponieważ nie dopuszczała ona do osiagnięcia trwałego panowania nad rynkiem przez jakikolwiek podmiot. Gospodarka, której centralnym mechanizmem byłaby konkurencja jest w stanie dostarczać środków umożliwiających prowadzenie właściwej polityki społecznej, stając się podstawą mechanizmu łagodzenia konfliktów klasowych.

Stąd też państwo przyjęło na siebie odpowiedzialność za umacnianie ładu rynkowego, w ramach którego jest realizowana zasada wolnej konkurencji. Wykonuje ono dwojakiego rodzaju zadania: po pierwsze likwiduje grupy interesu lub ogranicza ich wpływy; po drugie kształtuje ład ekonomiczny bez bezpośredniego zajmowania się gospodarką. W ramach instytucjonalno-prawnych granic gospodarki wolnorynkowej ma miejsce gra rynkowa, w której indywidualni uczestnicy są niezdolni do podporządkowania sobie innych osób. Eucken zaznaczał, że przy niekontrolowanej wolnej konkurencji dochodzi zatem do podziału władzy i wpływów, co doprowadzić może do deformacji rynku i powstania monopoli ${ }^{17}$.

Występowanie jednocześnie obu zasad funkcjonowania rynku gwarantowało, według ordoliberałów, spełnianie zadań konkurencji, do których zaliczano: po pierwsze występowanie na rynku równowagi producentów i konsumentów, przy założeniu, że żaden z nich nie może uzyskać bezpośredniego wpływu na cenę; po drugie konkurencja odbywała się zgodnie z regułami obowiązującymi wszystkich uczestników.

System społecznej gospodarki rynkowej powinien funkcjonować w taki sposób, iż każde nowe pojawienie się podmiotu jako pracodawcy lub pracobiorcy na rynku budziłoby zainteresowanie ośrodków decyzyjnych. Dzięki temu walka konkurencyjna będzie mogła się odbywać, przy zrozumieniu tego co ma miejsce wewnątrz systemu politycznego, bez po-

16 Alexander Rüstow nie wahał się np. głosić poglądów o potrzebie powołania policji rynkowej, która bezpośrednio nadzorowałaby graczy rynkowych. Miałaby służyć wszystkim, gdyż zmuszałaby uczestników gry rynkowej do dostarczenia tylko tych dóbr i usług, na które zapotrzebowanie zgłaszaliby konsumenci.

17 W. Eucken, Podstawy polityki..., s. 69 i n. 
trzeby rozwiązania konfliktu między stronami ${ }^{18}$. Najważniejszym celem jest zatem zachowanie ładu rynkowego, który będzie osiagnięty przez współdziałanie wzajemnie powiązanych ze sobą elementów.

Dojrzewanie koncepcji społecznej gospodarki rynkowej sformułowanej w ostatecznym brzmieniu przez A. Müller-Armacka w 1946 r. zostało poprzedzone koncepcjami Rüstowa z 1932 r., oraz Röpkego ${ }^{19}$. Ta pierwsza, zwana koncepcją liberalnego interwencjonizmu, uznawała konieczność kontrolowania procesów zachodzących w gospodarce. Zakładała ograniczone oddziaływanie na rynek, w sposób nie poddający go totalnej kontroli ze strony państwa, lecz wzmacniając w nim skuteczność pewnych praw np. poprzez powiększenie ilości podmiotów biorących udział w grze rynkowej.

Röpke z kolei nawiązując do idei Rüstowa stworzył koncepcję zwaną: „pozytywną polityką gospodarczą" (związaną z deproletaryzacją i decentralizacja $)^{20}$, polegająca na wspieraniu rynku. W dziele „Die Gesellschaftskrisis der Gegenwart"21 Röpke zaproponował dwa sposoby oddziaływania na rynek. Pierwszy sposób, zwany „polityką ramową”, polegał na rozbudowie instytucji, które stanowiłyby podstawę rozwijania konkurencji na rynku, jako swoistego fundamentu gospodarki rynkowej. Natomiast drugim sposobem była tzw. ,,polityka rynkowa”, zwana dalej liberalnym interwencjonizmem. U jej podstaw znajdowały się dwie zasady: 1) zasada wdrażania interwencjonizmu dopasowującego; 2) zasada interwencjoniz$\mathrm{mu}$ tylko w granicach gospodarki rynkowej.

Pierwsza z nich polegała na złagodzeniu niedogodności rynku oraz wspieraniu słabych grup społecznych w celu utrzymania dużej liczby

18 Szerzej: R. A. Dahl, Dilemmas of Pluralist Democracy: Autonomy vs. Control, Yale University Press, New Haven.

19 R. Skarzyński, Państwo i społeczna gospodarka rynkowa..., op. cit., s. 7.

20 Deproletaryzacja oznacza nadanie w społeczeństwie charakteru powszechności własności prywatnej, przez co jednostki z osób nieposiadających środków produkcji staną się ich właścicielami. Poprzez skorelowanie postulatu deproletaryzacji z katolicką nauką społeczną doszłoby do próby przywrócenia harmonii pomiędzy jednostkami a społeczeństwem rozumianym jako zbiór jednostek. Röpke pisał, że „w dłuższym horyzoncie czasu, problem proletariatu może mieć tylko dwa ostateczne rozwiązania: po pierwsze, wszyscy ulegniemy proletaryzacji czy to w wyniku nagłej rewolucji (jak w Rosji), czy to stopniowo (jak w innych krajach); po drugie, przekształcimy proletariuszy w posiadaczy, dopełniając tego co encyklika papieska Quadrgesimo Anno trafnie określa mianem redemptio proletarium"; por. J. Lewandowski, Neoliberałowie wobec.., op. cit., s. 103.

21 Szerzej: W. Röpke, Die Gesellschaftskrisis der Gegenwart, Bern 1979. 
podmiotów na rynku. Jego zdaniem istnieją takie dziedziny: jak rolnictwo, rzemiosło, drobna przedsiębiorczość, które wymagają specjalnej ochrony, ponieważ spełniają one funkcję stabilizującą w społeczeństwie. Druga zasada polityki rynkowej uzasadniała tymczasem wdrażanie interwencjonizmu tylko na podstawie zasad przewidzianych w gospodarce rynkowej niedopuszczając jednocześnie do wszelkich innych form ingerencji, ponieważ doprowadziłoby to do rozwoju kolektywizmu.

3.

Pojęcie i istota społecznej gospodarki rynkowej została po raz pierwszy przedstawiona przez Müllera-Armacka w 1946 r. $^{22}$ Koncepcja ta miała charakter całościowy, polegający na tym, że dojdzie do pogodzenia wolnej przedsiębiorczości, zrodzonej na bazie ludzkiej inicjatywy, z zabezpieczeniami socjalnymi. W tym celu przyjęto dwa założenia: po pierwsze - wolny rynek jest instytucją, która umożliwia najbardziej dynamiczną aktywność człowieka, co prowadzi do wzrostu wydajności jego pracy; po drugie - konieczna jest realizacja zabezpieczeń społecznych, aby tym, którzy nie mogliby sprostać wyzwaniom rynkowym zapewnić godne życie.

Ład gospodarki rynkowej to rozwinięta w procesie historycznym forma organizacyjna. Państwo, poprzez specyficzne położenie rynku, dba o to, żeby jednostka zdobyła sobie znaczenie przez swoją wydajność. W ten sposób społeczna gospodarka rynkowa umożliwia postęp i znalezienie przez jednostkę miejsca w społeczeństwie w zależności od własnej przedsiębiorczości. Müller-Armack mawiał iż: „,nie można spoglądać tylko na procesy rynkowe, ale trzeba widzieć organizację państwową, która poprzez opodatkowanie i zabezpieczenia społeczne (w tym ubezpieczenie społeczne, renty, dodatki mieszkaniowe, premie) ma korygować tworzenie dochodów".

Tak rozumiany porządek rynkowy wymaga ingerencji państwa. Po pierwsze, państwo powinno dbać o to, aby zasada wolnej konkurencji była przestrzegana, ponieważ tylko wtedy rynek może spełniać przewidziane dla niego funkcje. Stąd konieczność zwalczania monopoli. Po drugie, państwo powinno stworzyć pewnego rodzaju politykę stymulującą konkurencję, w przeciwnym razie odrodzą się tradycyjne związki i dojdzie do

22 Szerzej: A. Müller-Armack, Wirtschaftslenkung und Marktwirtschaft, Hamburg 1947. 
podziału wpływów na rynku. Po trzecie, państwo powinno także dbać o właściwą strukturę gospodarki, dążyć do zagwarantowania możliwie wysokiego poziomu zatrudnienia czy też wspomagania procesów pobudzających koniunkturę. Interwencjonizm ma też obejmować budownictwo, handel zagraniczny, ceny i kredyty.

W aspekcie strukturalnym Müller-Armack postulował podobne założenia jak Röpke. Mianowicie odnosił się do deproletaryzacji, decentralizacji, a następnie odrodzenia małych i średnich przedsiębiorstw. Głosił tezy odnoszące się do rekonstrukcji stosunków panujących w zakładach pracy w celu przywrócenia podmiotowości osobom zatrudnionym. Stanowiło to zalążek idei oparcia działalności przedsiębiorstw i zakładów na szerokim samorządzie pracowniczym, w którym zrzeszony byłby czynnik pracowniczy obok czynnika zarządzającego ${ }^{23}$.

Polityka gospodarcza winna przyjąć za cel zabezpieczenie ludności przed skutkami kryzysu, czemu służyłyby w szczególności inwestycje państwowe, które pobudzałyby koniunkturę gospodarczą. Państwo niemieckie, po drugiej wojnie światowej - tworząc nowe miejsca pracy np. w budownictwie mieszkaniowym, podjęło próbę rozwinięcia systemu ubezpieczeń społecznych dla pracowników, gwarantując przy tym płace minimalne poprzez odpowiednie umowy określone w ustawach.

W ramach społecznej gospodarki rynkowej oprócz wymagań stawianych członkom społeczeństwa wyodrębniono także zasady indywidualnej działalności jednostek, które opierają się na korzystaniu z możliwie jak największego zakresu wolności. Oczekuje się, że jednostka zaistnieje na rynku, będzie samodzielna i odpowiedzialna za swoje działania. Może zatem być pracownikiem najemnym lub przedsiębiorca, dzięki temu uzyska odpowiednie dochody. Społeczna gospodarka rynkowa różni się tym od leseferystycznej wizji ekonomii, że człowiek, niespełniający wymagań stawianych przez rynek, posiada prawo do oczekiwania pomocy, pozwalającej mu na dalszą egzystencję. Jednostka zatem nie będzie pozostawiona samej sobie, lecz w razie potrzeby będzie miała prawo oczekiwać pomocy ze strony państwa. Społeczeństwo w społecznej gospodarce rynkowej powinno cechować się daleko idącą integracją. Nie jest możliwe wyeliminowanie wszystkich konfliktów w społeczeństwie. Stąd też państwo powinno dążyć do upowszechnienia czynników spajających wspólnoty ludzkie w różnych sferach życia gospodarczego. W przytoczonych po-

23 R. Skarzyński, Państwo i społeczna gospodarka rynkowa..., op. cit., s. 57 i n. 
glądach Müllera-Armacka można odnaleźć żywą ideę samorządu gospodarczego, która będzie polegała na tworzeniu form zdecentralizowanej administracji publicznej w sferze gospodarki.

\section{4.}

Ordoliberalna koncepcja społecznej gospodarki rynkowej została urzeczywistniona w Niemczech Zachodnich po drugiej wojnie światowej w polityce ministra gospodarki i wicekanclerza Ludwiga Erharda. Epoka wdrażania społecznej gospodarki rynkowej przypadała w Niemczech na lata 1949-1963, zwane także okresem adenauerowskim ${ }^{24}$. Koncepcja Müllera-Armacka jest ogólna. Warunkiem jej realizacji jest pewien kompromis polityczny, oparty na ograniczeniu konkretnych interesów w imię stabilizacji ładu społecznego. Interesy grup społecznych muszą uwzględnić wymagania stawiane przez system gospodarczy i społeczny, tworząc pewną całość. Stąd też w okresie pierwszego rządu Konrada Adenauera w latach 1949-1953 utworzono koalicję CSU/CDU z FDP, a nie z SPD na czele z oponentem Schmuacherem, a po jego śmierci 20 sierpnia $1952 \mathrm{r}$. z Erichem Ollenhauerem. Koalicja CSU/CDU z FDP zmierzała w polityce wewnętrznej do wprowadzenia społecznej gospodarki rynkowej ${ }^{25}$.

Po drugiej wojnie światowej uwarunkowania społeczno-ekonomiczne stanowiły podstawę budowania reprezentacji środowiska gospodarczego w Niemczech. Szczególnie należy podkreślić zmiany w zakresie powstawania izb rolniczych i przemysłowo-handlowych wynikające z podziału Niemiec na cztery strefy okupacyjne: brytyjską, amerykańską, radziecką oraz francuską.

W pierwszych latach po zakończeniu wojny, przed powstaniem RFN, odbudowa izb gospodarczych, zlikwidowanych w okresie hitleryzmu, przebiegała w każdej strefie okupacyjnej inaczej; różne były doświadczenia zwycięzców w tej dziedzinie. Na przykład Amerykanie i Anglicy nie mieli zrozumienia dla związków publicznoprawnych reprezentujących interesy gospodarcze rolników, przemysłowców i kupców. Wynikało to stąd, że w krajach anglosaksońskich - w przeciwieństwie do krajów Europy kontynentalnej - ze względu na inne doświadczenia historyczne i poli-

${ }^{24}$ E. Cziomer, Historia Niemiec wspótczesnych 1945-2005, Warszawa 2006, s. 108 .

25 Ibidem, s. 110. 
tyczne nie wykształciły się w sferze życia publicznego korporacje publicznoprawne, jako podmioty zdecentralizowanej administracji państwowej; nie powstały izby samorządu gospodarczego w znaczeniu teorii prawa administracyjnego ${ }^{26}$. Jedynie we francuskiej strefie okupacyjnej, terytorialnie najmniejszej, odradzające się związki gospodarcze przyjmowały ustrój korporacji publicznoprawnej z obligatoryjnym członkostwem i władztwem administracyjnym. Natomiast w strefie radzieckiej, a później w Niemieckiej Republice Demokratycznej, samorząd nie odrodził się w żadnej postaci.

Różnice o charakterze politycznym i gospodarczym między Republiką Federalną Niemiec a autorytarną Niemiecką Republiką Demokratyczną polegały na tym, że pierwsza z nich przyjęła ustrój demokracji obywatelskiej, w którym administracja państwowa miała charakter dychotomiczny: dzieliła się na scentralizowaną administrację rządową i zdecentralizowaną administrację samorządową. Samorząd jako „samodzielne wykonywanie zarządu przez bezpośrednio zainteresowanych"27 stał się jednym z najważniejszych filarów ustroju RFN.

Jak wspomniano wyżej społeczna gospodarka rynkowa jest oparta na szerokiej decentralizacji w sferze gospodarczej. Wśród zalet decentralizacji wymienia się: wykonywanie zadań publicznych przez bezpośrednio zainteresowane osoby, a przez to lepsze rozumienie potrzeb lokalnej społeczności, krótszy czas podejmowania i realizacji decyzji, łatwiejsze dostosowanie się do zmieniających się warunków oraz skuteczną kontrolę wydawanych środków ${ }^{28}$. Samorząd legitymizował obywatelski i demokratyczny charakter ustroju zachodniej państwowości niemieckiej. Stopniowo, ale nie bez trudności, odradzały się jego desygnaty: samorząd terytorialny, zawodowy i gospodarczy; ten ostatni zinstytucjonalizowany w izbach przemysłowo-handlowych, rzemieślniczych i rolniczych ${ }^{29}$.

26 Por. W. Kluth, Entwicklungsgeschichte und aktuelle Rechtsgrundlagen..., w: Handbuch des Kammerechts, pod red. W. Kluth, Halle 2005, s. 36-37.

27 G. Jellinek, Allgemeine Staatslehre, Berlin 1928, s. 629.

28 S. Wykrętowicz, Samorzad jako wyraz demokracji obywatelskiej, w: Samorzad w Polsce. Istota, formy i zadania, pod red. S. Wykrętowicza, Poznań 2001, s. 55.

29 W doktrynie niemieckiego prawa konstytucyjnego i prawa administracyjnego ustawodawca wyróżnił podział na samorząd terytorialny, zwany także powszechnym, oraz na samorząd specjalny. Samorząd specjalny w języku niemieckim thumaczy się jako „funktionalne Selbstverwaltung”, por. W. Frotscher, U. Kramer, Wirtschaftsverfassungs - und Wirtschaftsverwaltungsrecht. Eine systemathische Einfuehrung anhand von Grundfaellen, Muenchen 2004, s. 286-287. W ramach samorząu 
W powojennej RFN sfera gospodarcza została zdecentralizowana w największym stopniu. Samorząd gospodarczy w postaci izb przemysłowo-handlowych, izb rolniczych i izb rzemieślniczych stał się integralnym elementem ustroju państwa niemieckiego. Dzięki instytucjom samorządu gospodarczego, we współzarządzaniu w sferze życia społeczno-gospodarczego brały udział bezpośrednio zainteresowane jednostki reprezentujące środowisko: przemysłowców, kupców, rzemieślników i rolników (wspólnoty samorządowe wyposażone we władztwo administracyjne) ${ }^{30}$.

Po drugiej wojnie światowej jako pierwsze odrodziły się izby przemysłowo-handlowe. Ich zalążkiem było powstania w $1945 \mathrm{r}$. tzw. związku jedności pracy, który ostatecznie zatwierdziły władze okupacyjne dopiero w marcu 1946 r. Niecałe dwa lata później - 4 grudnia 1947 r. w Kassel powołano izbę przemysłowo-handlową wspólną dla Bizonii - czyli połączonych stref amerykańskiej z brytyjską. Przewodniczący izby dr Alfred Petersen stanął przed ważkim zadaniem wyboru doktryny ekonomicznej, na podstawie której miała funkcjonować izba. W 1949 r. Petersen już jako Prezydent Izby Przemysłowo-Handlowej odrzucił model gospodarki sterowanej przez państwo opowiadając się za gospodarką rynkową i wolnym handlem. W swoich licznych wystappieniach wielokrotnie podkreślał, że istota społecznej gospodarki rynkowej „nie polega na wolności przedsiębiorczej w sensie bezsystemowego liberalizmu, ale na wolności w granicach socjalnej odpowiedzialności, która stanowi element składowy tej gospodarki ${ }^{31}$. Petersen głosił, że „człowiek i narody powinny nareszcie nauczyć się burzyć granice gospodarcze między krajami dla dobra ogółu i dla dobra jednostki"32. Społeczna gospodarka rynkowa dąży do zagwarantowania stabilnego i zrównoważonego ładu społecznego wszystkich

specjalnego wyróżnia się samorząd gospodarczy (Wirtschaftsselbstverwaltung) i zawodowy (na oznaczenie samorządu zawodowego używa się pojęcia „,berufssständiche Selbstverwaltung" - co oznacza samorząd osób czynnych zawodowo, por. P. Badura, Wirtschaftsverfassung und Wirtschaftsverwaltung, Muenchen 2005, s. 231. Oprócz samorządu zawodowego i gospodarczego funkcjonuje także podział na samorząd akademicki, studencki, kulturalny oraz społeczny. Jednostkami samorządu są zatem oprócz gmin, powiatów także: izby przemysłowo-handlowe, rzemieślnicze, rolnicze, adwokackie, lekarskie, ubezpieczeniowe, uniwersytety, cechy oraz publiczne stacje radiowe, por. R. Hendler, Geschichte und Idee der funktionalen Selbstverwaltung, w: Handbuch des Kammerechts, pod red. W. Kluth, Halle 2005, s. 25.

30 Por. S. Cyganek, Izby przemystowo-handlowe w Polsce..., op. cit., s. 29.

31 Ibidem, s. 79.

32 Zeugnisse der Zeit. 125 Jahre Deutscher Industrie - und Handelstag, Deutscher Industrie - und Handelstag (DIHT), Bonn 1986, s. 11. 
grup społecznych; dopuszcza interwencjonizm państwa w sferze ustawodawstwa gospodarczego i socjalnego.

Powstanie w 1949 r. Republiki Federalnej Niemiec stworzyło przesłanki ujednolicenia podstaw prawnych samorządu gospodarczego w nowopowstałym państwie. Ze względu na federalny charakter państwa, izby gospodarcze, jako instytucje samorządu gospodarczego znalazły umocowanie prawne zarówno w ustawach federalnych, jak i krajowych ${ }^{33}$. Oczywiście, jedne i drugie ustawy mieszczą się w ramach ogólnych norm ustawy zasadniczej, czyli tymczasowej Konstytucji federalnej z 23 maja 1949 roku ${ }^{34}$.

W przypadku izb przemysłowo-handlowych istnieje ustawodawstwo dwupoziomowe: federalne i krajowe. Ustawa federalna z 18 grudnia $1956 \mathrm{r}^{35}$ stanowi o fundamentalnych podstawach ustroju prawnego izb, takich jak: podmiotowość publicznoprawna, obligatoryjne członkostwo i władztwo administracyjne. Wskazuje na konstytutywne cechy, które czynią z nich podmioty zdecentralizowanej administracji państwowej. Natomiast takie kwestie, jak zadania izb i ich zakres przedmiotowy, sposób wyłaniania organów władzy i ich kompetencje - wszystkie te i inne kwestie wynikające $z$ położenia geograficznego lub potencjału społeczno-gospodarczego landu określają ustawy krajowe ${ }^{36}$. Izbom przemysłowo-handlowym przekazano pełnienie funkcji ,orędownika społecznej gospodarki rynkowej i wolnej inicjatywy przedsiębiorstw w granicach socjalnej odpowiedzialności" ${ }^{37}$.

Inaczej jest w przypadku izb rolniczych, tutaj całość spraw związanych z powoływaniem izb rolniczych, ich organizacją i funkcjonowaniem jako podmiotów zdecentralizowanej administracji publicznej została - na mocy wspomnianej Konstytucji federalnej (art. 30 i 83) (38 $^{38}$ przeniesiona

33 S. Cyganek, Izby przemystowo-handlowe $w$ Polsce..., op. cit., s. 37.

34 Grundgesetz für die Bundesrepublik Deutschland vom 23. Mai 1949, BGB1. S. 1.

35 Gesetz zur vorläufigen Regelung des Rechts der Industrie- und Handelskammern vom 18 Dezember 1956, BGBl. S. 920.

36 S. Cyganek, Izby przemystowo-handlowe w Republice Federalnej Niemiec, w: Samorzad w Polsce. Istota, formy, zadania, pod red. S. Wykrętowicza, Poznań 2008, s. 373.

37 S. Cyganek, Izby przemysłowo-handlowe w Republice Federalnej Niemiec..., op. cit., s. 79.

38 Art. 30 ,realizacja uprawnień władzy państwowej i wykonywanie zadań państwowych należy do władz krajów związkowych o ile ustawa zasadnicza nie stanowi inaczej lub nie dopuszcza innych regulacji prawnych".

Art. 83. Stanowi, że „kraje związkowe wykonują ustawy federalne jako własną sprawę, o ile ustawa zasadnicza nie stanowi inaczej lub nie dopuszcza innej możliwości”. 
na kraje związkowe. Każdy land posiada zatem własne regulacje prawne dotyczące izby rolniczej na jego terenie ${ }^{39}$.

Pierwszym aktem prawnym, który wprowadził izby rolnicze w Republice Federalnej Niemiec była ustawa Landtagu Północnej Nadrenii Westfalii z 11 lutego $1949 \mathrm{r}^{40}$ Na mocy tej ustawy powstała pierwsza w RFN Izba Rolnicza Północnej Nadrenii Westfalii. Ustawa ta stała się wzorem dla innych landów, które miały potrzebę powołania na swoim obszarze izby rolniczej ${ }^{41}$. Wzorem tej ustawy niemieckie izby rolnicze są korporacjami prawa publicznego, a przynależność do nich jest obligatoryjna ${ }^{42}$; dzięki tym konstytutywnym cechom izby rolnicze posiadają władztwo administracyjne, czyli zdolność do wykonywania określonych w ustawie zadań w dziedzinie rolnictwa ${ }^{43}$; są podobnie jak izby przemysłowo-handlowe i rzemieślnicze podmiotami zdecentralizowanej administracji publicznej w „pewnej przestrzeni życiowej”, w której funkcjonują. Tą „,przestrzenią” jest rolnictwo ${ }^{44}$.

Jak wiadomo, Republika Federalna Niemiec należy do najwyżej uprzemysłowionych i zurbanizowanych państw świata. W 2004 r. około 88\%

39 Regulacje prawne dotyczące powoływania izb rzemieślniczych zostały zawarte w ustawie z dnia 17.09.1953 roku o rzemiośle ze zmianami; Gesetz zur Ordnung des Handwerks v. 17.09.1953, BGBl I 1953, 1411; Gesetz zur Ordnung des Handwerks v. 24. 9.1998 I 3074, v. 11.12.2008 I 2418.

${ }^{40}$ Gesetz über Landwirtschaftskammer Nordrhein - Westfalen v. 11.2.1949, GV NW. S. 53. 23.12.2003, GV NW. S. 808.

41 A. Werenowska, Organizacja izb rolniczych wybranych krajach UE, „Zeszyty Naukowe Akademii Rolniczej im. H. Kołłątaja w Krakowie”, z. 78, nr 377, Kraków 2000, s. 424.

42 Por. $§ 20$ ust. 1 ustawy o Izbie Rolniczej Północnej Nadrenii Westfalii z 11 lutego 1949 r. stwierdza, że izby rolnicze posiadają osobowość publicznoprawną oraz obligatoryjne członkostwo; szerzej: W. Frotscher, U. Kramer, Wirtschaftsverfassungsund Wirtschaftsverwaltungsrecht..., op. cit., s. 295. W § 23 ust. 4 ustawy o organizacji samorządu rolniczego w Północnej Nadrenii Westfalii z 10.07.1962 r., wskazano jednoznacznie, że izby rolnicze są podmiotami prawa publicznego, Gesetz über die Organisation der Landverwaltung vom 10.7.1962, GV NW S. 241, zmieniona przez ustawę z 9.5.2000, GV NW S. 462.

43 K. Stollreither, Verfassung des Freistaates Bayern. Grundgesetz fuer die Bundesrepublik Deutschlands. Ueberblick ueber Europaeische Union. Der Bayerische Landtag. Funktionen und Aufgaben, Augsburg 2007, s. 132-161.

44 R. Stasikowski, Gwarancje samorzqdności gminnej w systemie prawnym Republiki Federalnej Niemiec i Rzeczypospolitej Polskiej, s. 19; por. R. Hendler, Geschichte und Idee der funktionalen Selbstverwaltung, w: Handbuch des Kammerechts, pod red. W. Kluth, Halle 2005, s. 25. 
ludności tego kraju zamieszkiwało w miastach, a $12 \%$ na wsi ${ }^{45}$. W związku z tym, o ile izby przemysłowo-handlowe działają we wszystkich 16 krajach związkowych, to izby rolnicze zaledwie w 7; odpowiednio izb przemysłowo-handlowych funkcjonuje w Niemczech 83, a izb rolniczych zaledwie 7. Przeciętna liczba członków niemieckiej izby rolniczej liczy ok. 200 tys. członków. Dodać należy, że w krajach związkowych wchodzących przed zjednoczeniem Niemiec do Niemieckiej Republiki Demokratycznej nie powołano dotąd żadnej korporacji samorządu gospodarczego.

W myśl koncepcji społecznej gospodarki rynkowej państwo w celu zapewnienia prawidłowej reprezentacji interesów społeczeństwa utworzyło infrastrukturę gospodarczą. Infrastrukturę tę stanowią: izby przemysłowo-handlowe, izby rolnicze i rzemieślnicze. W wyniku decentralizacji państwo przekazało im wiele ważkich zadań, które wcześniej wykonywała administracja rządowa. Izby jako korporacje publicznoprawne posiadają władztwo administracyjne i zdolność do wykonywania zadań publicznych. Zadania te dzielą się na zadania własne, wymienione w poszczególnych ustawach regulujących ustrój i zadania izb oraz zadania zlecone. W obu przypadkach izby realizują owe zadania samodzielnie i na własną odpowiedzialność oraz w wykonywaniu tych zadań są niezależne od innych organów władzy państwowej, głównie administracji rządowej i samorządowej ${ }^{46}$. Izby nie tylko z racji sąsiedztwa ze swoimi członkami wykonują swoje zadania efektywniej i skuteczniej, ale także z perspektywy aparatu centralnego (rządowego).

W ustawodawstwie landów istota samorządności izb, podobnie jak wszystkich innych instytucji samorządu w rozumieniu teorii prawa administracyjnego, polega na dwóch zasadach: Betroffenenmitwirkung, czyli udziale osób w sprawach, które ich bezpośrednio dotyczą oraz Eigenverantowortlichkeitsprinzip, która zakłada, że izby wykonując własne zadania i zlecone z zakresu administracji publicznej ponoszą pełną odpowiedzialność za ich realizację.

Zmiana doktryny ekonomicznej w Niemczech Zachodnich po drugiej wojnie światowej generuje pytanie o potrzebę zmiany dzisiejszej doktry-

45 Niemcyi Ludność, w: Encyklopedia Świata i Polska, PWKN 2007, s. 286.

46 W. Kluth, Funktionale Selbstverwaltung, Halle 1997, s. 325. 
ny ekonomicznej w Polsce. Implementacja koncepcji społecznej gospodarki rynkowej po 1948 roku w Republice Federalnej Niemiec została w pełni urzeczywistniona przez jednostki samorządu gospodarczego. Stanowi ona przykład i zarazem inicjatywę do podjęcia dyskusji o przyszłość polskiej gospodarki.

W wyniku obserwacji polskiego systemu ekonomicznego rozwiązania o charakterze całościowym wydają się być niezbędne. W przejściu od neoliberalizmu do koncepcji społecznej gospodarki rynkowej ogromna rolę powinny odegrać jednostki samorządu terytorialnego, jak i specjalnego, czyli gospodarczego i zawodowego, podobnie jak miało to miejsce w Niemczech Zachodnich. Potrzebna jest zatem siła polityczna, która tak jak chadecja w powojennych Niemczech potrafiłaby przyjąć ideologię łączącą inne ugrupowania polityczne, a nie podkreślającą wzajemne antagonizmy. W Polsce nie ma realnie funkcjonujących partii opierających się na doktrynie społecznej nauki kościoła, stąd też brakuje sił politycznych, które odrzuciłyby neoliberalizm, a wprowadziły system gospodarczy stanowiący jego alternatywę: społeczną gospodarkę rynkową, opartą na wolności gospodarczej i odpowiedzialności socjalnej; gospodarkę opartą na symetrii interesów przedsiębiorców i pracowników. W Polsce żadna z liczących się sił politycznych ani na prawicy, ani na lewicy takiej alternatywy nie reprezentuje; wszystkie te opcje polityczne stoją na gruncie doktryny neoliberalizmu, jego filozofii anglosaksońskiego indywidualizmu i egoizmu, podzielając za Miltonem Friedmanem - pogląd, że ,istnieje jeden: tylko jeden obszar odpowiedzialności w biznesie - wykorzystanie wszelkich środków i zaangażowanie się w działania, które mają na celu zwiększenie zysków firmy [...]"47. Owa asymetria interesów między kapitałem a pracą leży u podstaw obecnego kryzysu światowego w sferze finansowej i realnej produkcji społecznej.

Kryzys ten nie omija Polski. Dwadzieścia lat funkcjonowania polskiej gospodarki wolnorynkowej ukazało, iż implementacja terapii szokowej, czyli wprowadzenie w 1989 roku gospodarki kapitalistycznej było procesem udanym z racji zahamowania narastającej inflacji, a z drugiej strony nieudanym, ponieważ wprowadzono zbyt gwałtownie zmiany w społeczeństwie polskim nieprzygotowanym do zmierzenia się z rzeczywistością wolnorynkową. Negatywne konsekwencje niefortunnych reform

47 M. Friedman, Capitalism and Freedom, Chicago 1962, s. 133, za: L. Ryan, Etyka a wyniki finansowe firmy: amerykańskie punkty widzenia, w: Etyka biznesu w działaniu: doświadczenia i perspektywy, red. W. Gasparski, J. Dietl, Warszawa 2001, s. 93. 
doprowadziły do pogłębienia się kryzysu systemu politycznego, ekonomicznego oraz społecznego. Stąd też zaistniała potrzeba wprowadzenia koncepcji trzeciej drogi, która doprowadziłaby do przewartościowania istniejącego ładu społecznego w obliczu kryzysu finansowego pierwszej dekady XXI wieku ${ }^{48}$.

Przezwyciężenie skutków tego kryzysu ze względu na jego głębię i zasięg wymagają alternatywnej zmiany doktryny ekonomicznej: odrzucenia neoliberalizmu i przywrócenia konstytucyjnej podstawy ustroju gospodarczego Rzeczypospolitej Polskiej, którą stanowi społeczna gospodarka rynkowa; przywrócenie do życia martwego dotąd 20 artykułu Konstytucji RP, w którym czytamy: „społeczna gospodarka rynkowa oparta na wolności działalności gospodarczej, własności prywatnej oraz solidarności, dialogu i współpracy partnerów społecznych [czyli symetrii interesów przedsiębiorców i pracowników - M.B.], stanowi podstawę ustroju gospodarczego Rzeczypospolitej Polskiej"

$$
* * *
$$

Podsumowując należy zaznaczyć, że liberalna gospodarka rynkowa nie jest autonomiczna, dlatego też nie może pełnić funkcji regulatora i stabilizatora ładu ${ }^{50}$. Podlega wielu wpływem zewnętrznym, co doprowadza do deregulacji jej mechanizmów, zdeformowania wolnej konkurencji oraz prawa popytu i podaży. Sam rynek nie tworzy zatem żadnych wartości kulturowych, ani nie umiejscawia człowieka w społeczeństwie. Ład społeczny nie może funkcjonować tylko dzięki związkom ekonomicznym. Jeżeli rynkowi powierzy się funkcję regulatora życia społecznego, jak miało to miejsce w Polsce po transformacji ustrojowej, sytuacja ta doprowadzi nie tylko do podważenia ładu ekonomicznego, ale przede wszystkim ładu społecznego. W obliczu światowego kryzysu finansowo-gospodarczego, który nie oszczędził również Polski, potrzeba alternatywnej zmiany doktryny ekonomicznej - odrzucenie neoliberalnej gospodarki rynkowej i przywrócenie ordoliberalnej społecznej gospodarki rynkowej stanowi impuls do podjęcia rozważań nad wprowadzeniem tej koncepcji w Polsce.

48 Por. J. F. Stiglitz, Globalizacja, Warszawa 2005, s. 164.

49 Konstytucja Rzeczypospolitej Polskiej z dnia 2 kwietnia 1997 r., Dz. U. Nr 78, poz. 489 , art. 20.

50 R. Skarzyński, Państwo i społeczna gospodarka rynkowa..., op. cit., s. 57 i n. 


\section{Summary}

After WWII the Federal Republic of Germany needed to choose an economic system for itself which resulted in having to identify a third way - one between liberalism and collectivism. The Ordoliberal concept of social market economics was the best response to the spirit of transformations that occurred in West Germany after 1949. Minister of Economics and former Vice Chancellor, Ludvig Erhard performed market reforms following the spirit of Ordoliberalism over the period of 1949-1963. The purpose of this paper is to make Polish readers acquainted with the model of a social market economy, i.e. a market economy including social responsibility, implemented by the units of economic self-government - chambers of commerce and industry, chambers of agriculture and of crafts. 